\title{
The Role of Technological Teaching Methods Used in Education on the Development
}

\section{Aslı ÖZTOPCU}

Asist. Prof. Dr., Departmant of Banking and Insurance at Maltepe University

Lecturer Diğdem ENEREM

Department of Child Development at Maltepe University

\begin{abstract}
Different teaching methods are used to make individuals' learning easier and effective. Technological teaching tools are often used in this context. Technological teaching methods create socioeconomic effects while increase human capital, because investments made in human beings provide benefits, both for individuals and society in a long term. In this study, firstly the use of technological teaching methods is investigated and secondly, the role of the gains obtained in the development is analyzed. According to the results obtained, technological teaching methods cause externalities such as reduction of crime rates, revitalization of the economy thanks to investments, increase in the quality of relations of civil society, increase in $\mathrm{HDI}$ and increase in employment.
\end{abstract}

Keywords: Education, Educational technology, Teaching methods, Development 